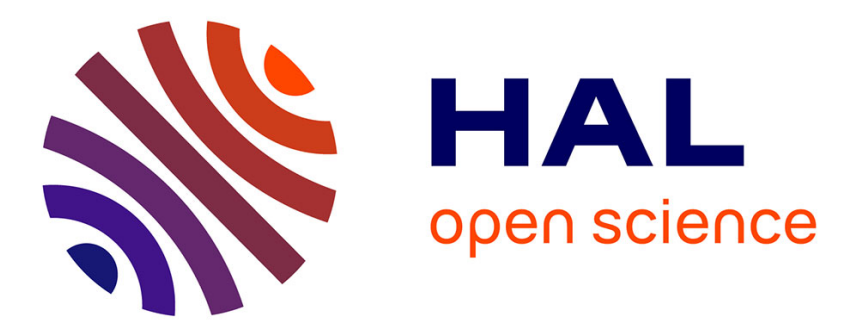

\title{
A Langmuir Probe - fluxgate magnetometer combination for Comet Interceptor
}

Johan de Keyser, Sylvain Ranvier, Jeroen Maes, Jordan Pawlak, Eddy Neefs, Frederik Dhooghe, Uli Auster, Bernd Chares, Niklas Edberg, Jesper Fredriksson, et al.

\section{To cite this version:}

Johan de Keyser, Sylvain Ranvier, Jeroen Maes, Jordan Pawlak, Eddy Neefs, et al.. A Langmuir Probe - fluxgate magnetometer combination for Comet Interceptor. Europlanet Science Congress 2021, Sep 2021, Virtual Meeting, France. 10.5194/epsc2021-285 . hal-03536601

\section{HAL Id: hal-03536601 https://hal.science/hal-03536601}

Submitted on 20 Jan 2022

HAL is a multi-disciplinary open access archive for the deposit and dissemination of scientific research documents, whether they are published or not. The documents may come from teaching and research institutions in France or abroad, or from public or private research centers.
L'archive ouverte pluridisciplinaire HAL, est destinée au dépôt et à la diffusion de documents scientifiques de niveau recherche, publiés ou non, émanant des établissements d'enseignement et de recherche français ou étrangers, des laboratoires publics ou privés. 
EPSC Abstracts

Vol. 15, EPSC2021-285, 2021

https://doi.org/10.5194/epsc2021-285

Europlanet Science Congress 2021

(C) Author(s) 2022. This work is distributed under

the Creative Commons Attribution 4.0 License.

\section{A Langmuir Probe - fluxgate magnetometer combination for Comet Interceptor}

Johan De Keyser ${ }^{1}$, Sylvain Ranvier ${ }^{1}$, Jeroen Maes ${ }^{1}$, Jordan Pawlak ${ }^{1}$, Eddy Neefs ${ }^{1}$, Frederik Dhooghe $^{1}$, Uli Auster ${ }^{2}$, Bernd Chares ${ }^{2}$, Niklas Edberg ${ }^{3}$, Jesper Fredriksson ${ }^{3}$, Walter Puccio ${ }^{3}$, Pierre Henri ${ }^{4}$, Olivier Le Duff ${ }^{4}$, Joakim Peterson ${ }^{5}$, and Magnus Oja ${ }^{5}$

${ }^{1}$ Royal Belgian Institute for Space Aeronomy, Space Physics, Brussels, Belgium (johan.dekeyser@aeronomie.be)

${ }^{2}$ Technische Universität Braunschweig, Germany

${ }^{3}$ Institutet for Rymdfysik, Uppsala, Sweden

${ }^{4}$ LPC2E, Orléans, France

${ }^{5}$ Institutet for Rymdfysik, Kiruna, Sweden

ESA's Comet Interceptor mission is a low budget, fast track mission to a dynamically new comet (DNC). As a DNC enters the inner solar system for the first time, it is expected to feature strong activity and to display a fluid-scale plasma environment, rather than the kinetic-scale environment encountered at weakly active objects such as 67P. In situ characterization of this plasma environment is therefore one of the main mission objectives and is the object of the Dust-FieldsPlasma instrument, a suite of sensors for the measurement of the dust, the plasma populations, and the magnetic and electric fields and waves, with the field sensors being mounted on booms, all within strict mass, power, and budget constraints. In this context a sensor has been developed that harbors a fluxgate magnetometer at the center of a hollow spherical Langmuir probe. Precautions have been taken to minimize the possible interference between both, while at the same time being very lightweight. An engineering model has been built, tested and characterized in detail. Together with a companion Langmuir probe and an additional magnetometer in gradiometer configuration, the probe-magnetometer combination (COMPLIMENT + FGM) provides data regarding magnetic and electric fields and waves, total ion and electron densities and electron temperature, as well as the ambient nanodust population. It also offers reference data for the other sensors, such as magnetic field direction, spacecraft potential and total plasma density at high cadence, and integrated EUV flux. 